\title{
A sinuscsomó spontán automáciájának mechanizmusa: egy két évtizedes vita krónikãja
}

\author{
Nagy Norbert1,2, Varró András ${ }^{1,2}$, Tóth András ${ }^{1,2}$ \\ ${ }^{1}$ MTA-SZTE Keringésfarmakológiai Kutatócsoport, Szeged \\ ${ }^{2}$ SZTE-ÁOK, Farmakológiai és Farmakoterápiai Intézet, Szeged
}

Levelezési cím: Dr. Tóth András, SZTE-ÁOK Farmakológiai és Farmakoterápiai Intézet, 6720 Szeged, Dóm tér 12.

E-mail: toth.andras@med.u-szeged.hu

\begin{abstract}
A sinuscsomó spontán automáciája létfontosságú elektrofiziológia folyamat, amely pontos mechanizmusának a felderítése az 1950-es évek óta intenzív kutatás tárgya. Ezen felül, a spontán ingerképzés abból a szempontból is különleges, mert talán nem túlzás azt állítani, hogy az utóbbi három évtized talán legizgalmasabb vitáját váltotta ki az experimentális kardiológiában. Az évek során több uralkodó nézet létezett, amely igyekezett megmagyarázni a spontán ingerképzést, majd az egyre szaporodó és egyre korszerübb eszközökkel végzett kísérletes eredmények következtében többször is paradigmaváltásra került sor. Ebbe a sodró lendületű vitába az évtizedek alatt számos kutatócsoport bekapcsolódott, értékes eredményekkel gazdagítva tudásunkat, több esetben jelentős tudományos vitát generálva ezzel, mígnem eljutottunk a ma elfogadott szemléletig. Jelen közlemény célja, hogy összegezze a spontán automácia kutatásában elért legfőbb mérföldköveket, végigvezetve az olvasót az egyes uralkodó nézeteken, egészen a ma elfogadott álláspontig.

Kulcsszavak: sinus, funny-áram, spontán diasztolés depolarizáció, Ca²+óra, membrán óra
\end{abstract}

Mechanism of the sinus node spontaneous automacy: chronicle of two decades of debate

The discovery of the exact mechanism of sinus node pacemaking process has initiated intensive research from 1950. Furthermore, the spontaneous automaticity is particular because it generated perhaps one the most interesting debate in the past three decade of experimental cardiology. During these years several dominating hypothesis were existing to explain the pacemaking mechanism, and then by the increasing number of the available experimental results have lead to several change of the actual paradigm. Several laboratories provided important result promoting the research, often generating intensive debates until getting to the current accepted view. The aim of this study is to summarize the most important milestones in the research of spontaneous automaticity, guiding the reader through the dominant hypothesis to the actual accepted concept.

Keywords: sinus, funny-current, spontaneous diastolic depolarization, Ca-clock, membrane clock

\section{Bevezetés}

A szív folyamatos kontraktilis müködése az élet nélkülözhetetlen feltétele, amely a sinus (SA) csomóban zajló, összetett és precíz elektrofiziológiai müködés által válik lehetővé, amely minden külső idegi és hormonális szabályozástól függetlenül képes a szívizom kontrakcióját egy élethosszon át biztosítani. Nem meglepő ezek alapján, hogy a szív spontán automáciája már évszázadokkal korábban felkeltette a tudósok érdeklődését, azonban az igazi áttörés csak a XIX. század végén kezdődött, amikor Wilhelm His felfedezte a később róla elnevezett His-köteget, majd később Sunao Tawara az atrioventriculáris (AV) csomót, végül Arthur Keith és Martin Flack a sinuscsomót.

Az SA-csomó működése során folyamatos, ritmikus, spontán akciós potenciálokat (AP) generál, amelyek a pitvari munkaizomzaton és az AV-csomón keresztül tovaterjednek a kamrai munkaizomzat felé. A többi szívizomsejttől eltérően a SA-csomóban levő sejtek kontraktilis apparátusa meglehetősen fejletlen, ami jelzi, hogy ezen régió elsősorban elektromos funkciót lát el. 
Az első elektrofiziológia felvételek során (1) nyilvánvalóvá vált, hogy az SA-csomóban generált AP-k morfológiája jelentősen eltér a szívizom munkaizomrostjaiból regisztrált AP-kétól. A legnegatívabb membránpotenciál érték a kamrai, illetve a pitvari szívizomsejtekhez képest jelentősen depolarizáltabb értéket vesz fel ( 50 $\mathrm{mV}$ ), a depolarizáció fázisa lassabb és kisebb amplitúdójú. A platófázis gyakorlatilag hiányzik, és a repolarizációt követően egy úgynevezett lassú diasztolés depolarizáció (DD) kezdődik el, amely a küszöbpotenciált elérve újabb AP-t vált ki (2). Ennek következtében a DD mögött megbúvó elektrofiziológiai folyamatok tehetők felelősség a spontán automácia kialakulásáért, amelynek pontos müködése évtizedek óta vita tárgyát képzi a tudósok körében.

\section{Korai elképzelések a Purkinje-rost spontán automácia mechanizmusáról: az $I_{K 2}$-hipotézis}

A pacemaker-funkcióra vonatkozó első tudományos munkák elsősorban Purkinje-roston készültek, hiszen a spontán automácia ezen szövettípusban is jelen van, ugyanakkor sokkal könnyebben izolálható és tanulmányozható. Az 1960-as évek elején két fő repolarizáció áramot azonosítottak: az időfüggetlen, és befelé egyenirányító $\mathrm{I}_{\mathrm{K} 1}$-et $(3,4)$, valamint a lassú, és az időfüggő $\mathrm{I}_{\mathrm{K} 2} \mathrm{t} \mathrm{t}$ (5). A birka Purkinje-rostban is mérhető spontán $\mathrm{DD}$-ért az $\mathrm{I}_{\mathrm{K} 2}$-áram lassú deaktivációját, valamint a háttér-depolarizáló áramok együttmüködését tartották felelősnek $(6,7)$. Az elméletet tovább erősítette, hogy az $\mathrm{I}_{\mathrm{K} 2}$-áram adrenalin mediált $\beta$-adrenerg stimulációja fokozta a spontán automáciát (8).

\section{Az SA-csomó automáciảja: az If („,funny") áram felfedezése és szerepe}

Az adrenalin szívfrekvencia-fokozó szerepét SA-ban már megfigyelték (9), habár a közremüködő mechanizmus még ismeretlen volt. DIfrancesco és munkatársai 1979-ben nyúl SA-csomón leírtak egy új áramot, amelyet különleges tulajdonságai miatt „funny”-nak neveztek el $\left(I_{f}\right)(10)$, amelyből fakadóan felelőssé tehető az adrenalin által okozott frekvenciafokozó hatásért (11). Mivel az áram ionális hátterét ekkor még nem sikerült azonosítani, így azt sem tudták, hogy az $\mathrm{I}_{\mathrm{f}}$-áram azonos-e a Purkinjében leírt $\mathrm{I}_{\mathrm{K} 2}$-árammal. Megfigyelték azonban, hogy a két áram több szembeötlő hasonlóságot mutat:

- az $\mathrm{I}_{\mathrm{K} 2}$-hiperpolarizáció hatására deaktiválódik, ugyanabban a feszültségtartományban ahol az $\mathrm{I}_{\mathrm{f}}$ múködik.

- Az adrenalin hatása a két áramra nagyon hasonló. Egy évvel később, nyúl SA-csomón végzett kísérle- tek rávilágítottak arra, hogy a csökkent extracelluláris $\mathrm{Na}^{+}$jelentősen csökkenti az $\mathrm{I}_{\mathrm{K} 2}$-áram amplitúdóját, valamint az áram a külső $\mathrm{K}^{+}$-szintjétől is jelentősen függött, amely arra a konklúzióra vezetett, hogy kevert áramról lehet szó (12).

A fenti eredmény mérföldkőnek bizonyult a szív-elektrofiziológiában mivel felvetette a kérdést, hogy hogyan lehetséges, hogy két különböző áram ( $I_{f}$ és $\left.I_{k 2}\right)$, amelyek különböző ionális természettel rendelkeznek, két teljesen különböző szövettípusban ugyanazt a pacemaker mechanizmust hozzák létre.

\section{$A z I_{K 2}$ újraértelmezése - $A_{\text {„I }}$ funny" áram felfedezése Purkinje-rostban}

A kérdést 1981-ben sikerült megválaszolni a Purkinje-rostban levő $I_{K 2}$ reinterpretációja révén (13). Alacsony koncentrációjú $\mathrm{Cs}^{2+}$ ugyanis csökkentette az időfüggő $\mathrm{I}_{\mathrm{K} 2}$-áramot, így a teljes áram még inkább kl-felé haladóvá vált, jelezvén, hogy az $I_{K 2}$-áram inward természetü. $A$ $\mathrm{Ba}^{2+}$ jelenlétében elvégzett kísérletek pedig arra engednek következtetni, hogy az $\mathrm{I}_{\mathrm{K} 2}$-áram hiperpolarizációra nyílik és depolarizációra záródik. A vizsgálatok alapján világossá vált, hogy az $\mathrm{I}_{\mathrm{K} 2}$ nem lehet tiszta $\mathrm{K}^{+}$-áram, inkább egy -50 mV-nál negatívabb, hiperpolarizációra aktiválódó depolarizáló áram, amely bizonyította, hogy a Purkinje-rostban talált $I_{\mathrm{K} 2}$ valójában azonos az SA-csomóban korábban felfedezett $\mathrm{I}_{\mathrm{f}}$-árammal (13). Az $\mathrm{I}_{\mathrm{f}}$-nek a Purkinje-rost spontán automáciában betöltött szerepét egy másik munkacsoport is bizonyította 1983-ban (14).

\section{Az $\|_{\mathrm{f}}$ áram pontos természetének és szerepének feltárása \\ Biofizikai tulajdonságok}

Az 1980-as évek elején $\mathrm{BaCl}_{2}$-dal végzett kísérletek tisztázták, hogy az $\mathrm{I}_{\mathrm{f}}$-áram reverzál potenciálja $\left(\mathrm{E}_{\mathrm{f}}\right)$ a K-egyensúlyi potenciáltól pozitívabb tartományban található $(-20--30 \mathrm{mV})$, amely egyaránt függ mind a külső $\mathrm{Na}^{+}$valamint $\mathrm{K}^{+}$-szinttől, bizonyítva hogy a csatorna mindkét ionra permeábilis (15). Az áramfeszültség karakterisztika a membránpotenciál széles tartományában közel lineáris, azonban különösen alacsony extracelluláris $\mathrm{K}^{+}$-szinttel kl-felé egyenirányító tulajdonságot mutat (15). Mind a $\mathrm{Cs}^{2+}$ mind a $\mathrm{Rb}^{2+}$-ionok hatékonyan gátolták a csatornát (15).

\section{Korai elképzelések az autonóm idegrendszer frekvenciaszabályozásáról}

Régi megfigyelés hogy a frekvencia változása (mind a $\beta$-adrenerg, mind a muszkarin jelátvitel) befolyá- 
A

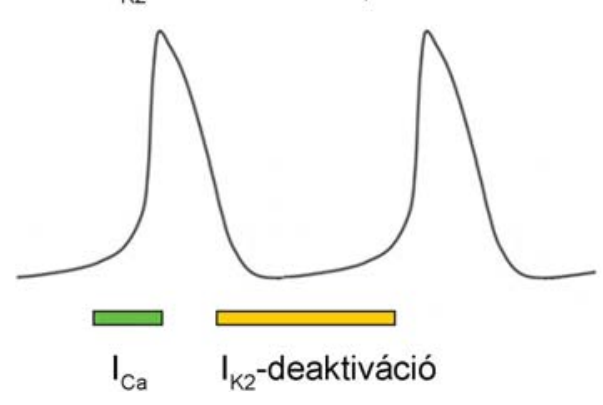

B

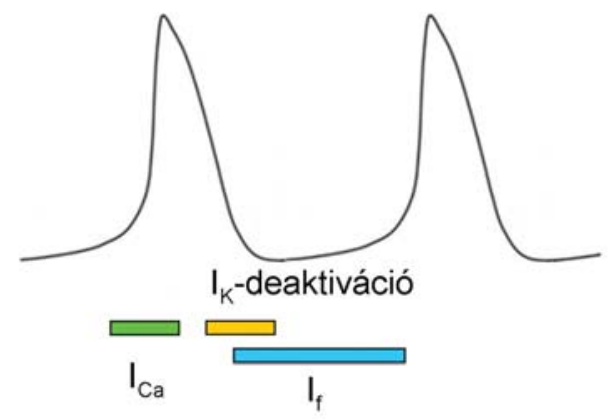

C $\quad \mathrm{Ca}^{2+}$-óra hipotézis

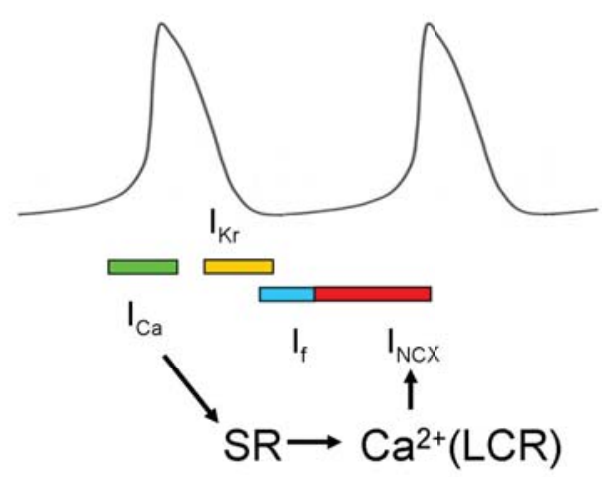

D Kapcsolt-óra hipotézis

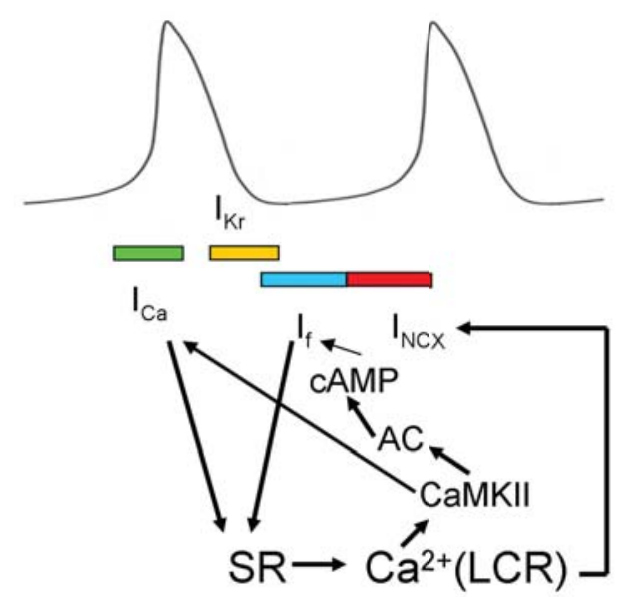

1. ÁBRA. Az SA-csomó spontán ingerképzésének hipotézisei. A: a legkorábbi magyarázat a DD kialakulását a repolarizáló K-áramok deaktivációjával értelmezte. B: A funny áram felfedezését követően a DD mechanizmusának elfogadott magyarázata az I I-áram révén létrejövő lassú depolarizáció volt. C: $\mathrm{A} \mathrm{Ca}^{2+}$-óra hipotézis az SR-ből spontán és ritmikusan felszabaduló Ca ${ }^{2+}$ jelentőségét hangsúlyozta, amely az NCX-en keresztül hozzájárul a diasztolés depolarizációhoz. D: Mai elfogadott nézet szerint az If és az NCX kapcsoltan múködik és az ingerképzés aktuális frekvenciáját együtt határozzák meg

solja az SA-csomó DD-nek meredekségét. Különösen fontos, hogy az alacsony dózisú izoprenalin $(0,1$ $\mu \mathrm{M}$ ) és acetilkolin (ACh; 0,01 $\mu \mathrm{M}$ ) nem befolyásolja a SAN AP konfigurációját, kizárólag a DD meredekségét növeli, illetve csökkenti. 1980-ban feltételezték, hogy a $\beta$-adrenerg aktiváció az adenilát-cikláz (AC) fokozásán keresztül növeli a cAMP-szintet, és fokozza az $\mathrm{I}_{\mathrm{f}}$-áramot. Hasonlóképpen, az ACh az $\mathrm{I}_{\mathrm{f}}$ aktivációs görbéjét negatívabb értékek felé eltolva csökkenti az áram relatív részvételét a spontán DDben $(16,17)$. Habár korábbi munkák eredményeképpen ismert volt, hogy az adrenalin fokozza az $\mathrm{I}_{\mathrm{K}}$-áramot is (18), valamint az ACh serkenti a kálium-permeábilitást egy speciális - akkor még nem pontosan ismert - speclfikus csatorna megnyitása által (19), a frekvenciaszabályzás elsődleges kontroll mechanizmusának az $\mathrm{I}_{\mathrm{f}}$-áram amplitúdójának modulálását tartották (20).

\section{Az $\left[\mathrm{Ca}^{2+}\right] i$ potenciális szerepe a frekvenciaszabályzásban: az If új kihívója}

Habár volt néhány eltérő elmélet, amely más mechanizmusok szerepét is hangsúlyozta a spontán automáciában, az I I-áram 1979-es felfedezésétől kezdve gyakorlatilag egyeduralkodó volt a spontán automácia mechanizmusának értelmezésében. Mind SAN-ban, mind Purkinje-rostban a spontán DD domináns mechanizmusának számított, valamint az autonóm idegrendszer által közvetített frekvenciamoduláció elsődleges mediátorának tartották, amely a DD meredekségének szabályozásával fokozza vagy csökkenti a spontán tüzelési frekvenciát. 1979-töl a 90-es évek közepéig hatalmas mennyiségú adat látott napvilágot az $\mathrm{I}_{\mathrm{f}}$-röl - gyakorlatilag számottevő cáfolat vagy kritika nélkül - és néhány, későbbi tudásunk alapján erősen kétséges eredményt $(21,22)$ leszámítva az $\mathrm{I}_{\mathrm{f}}$-elmélet nem talált méltó kihívó- 
ra. Így volt ez egészen 1996-ig, amikor is egy merőben új elmélet látott napvilágot. Rigg és munkatársai (23) 2 $\mu \mathrm{M}$ rianodin és $100 \mu \mathrm{M}$ ciklopiazonsav (rianodinreceptor-gátló) alkalmazásával depletálták az intracelluláris kalcium raktárt, amelynek eredményeképpen jelentős frekvenciacsökkenést ( 30\%) tapasztaltak, hangsúlyozván az intracelluláris $\mathrm{Ca}^{2+}$ szerepét a frekvenciaszabályozásban. Ezt a felfedezést követően, néhány év alatt számos publikáció került közlésre, amelyek megalapozták a $\mathrm{Ca}^{2+}$ ciklus szerepét a ritmusgenerálásban. Ezen közlemények legfontosabb megállapításai a következők: - a koffein gyors perfúzióban történő alkalmazása megállítja a SAN-sejtek spontán müködését 20 mp-re, amely arra utalhat, hogy az intracelluláris $\mathrm{Ca}^{2+}$-mozgások részt vehetnek a spontán automáciában. A 20 mp az újratöltődéshez szükséges idő lehet (24).

- A rianodin így az $\mathrm{SR} \mathrm{Ca}^{2+}$-tartalmának gátlása révén csökkenti a frekvenciát (25).

- Az [Ca $\left.{ }^{2+}\right]$ i a szarkolemmális $\mathrm{Na}^{+} / \mathrm{Ca}^{2+}$-kicserélő (NCX) forward módja révén hagyja el a sejtet, amely elektrogén pumpa révén depolarizáló, inward áramot generál. Így, az $\left[\mathrm{Ca}^{2+}\right] \mathrm{i}$ az NCX révén csatolódhat át membránpotenciál változásba, és közvetítheti az $\left[\mathrm{Ca}^{2+}\right]$ frekvenciamoduláló hatását. $\mathrm{Az} \mathrm{NCX}$-aktivitást $\mathrm{NiCl}_{2}$-al határozták meg $(25,26,21)$.

- Isoprenalinnal valamint alacsony és magas dózisú rianodinnal végzett kísérletek azt sugallják, hogy a $\beta$-adrenerg moduláció során létrejövő szívfrekvencia-fokozódás, legalább részben, az SR $\mathrm{Ca}^{2+}$-tartalom és NCX-áram növekedése által jön létre (27).

2001-ben Edward Lakatta munkacsoportja (28) egy újabb, mérföldkőnek számító megfigyeléssel vitték tovább a $\mathrm{Ca}^{2+}$-ciklus frekvenciaszabályozásban betöltött szerepének vizsgálatát. Macska spontán működő pitvari sejteken még a "hagyományos” $\mathrm{Ca}^{2+}$-tranziens kialakulása előtt az intracelluláris $\mathrm{Ca}^{2+}$ spontán emelkedését figyelték meg (local $\mathrm{Ca}^{2+}$ release $-\mathrm{LCR}$ ), amely rianodin szenzitív és az NCX-en átcsatolódva befolyásolja a DD-t. A rianodin negatív kronotróp hatása az AP-t megelőző $\mathrm{Ca}^{2+}$-hullámok eltűnésének tulajdonítható (28).

Ugyanez a kutatócsoport egy 2002-ben publikált közleményében megállapította, hogy a $\beta$-adrenerg moduláció következtében létrejövő pozitív kronotróp hatás kialakulásához intakt rianodin receptorokra van szükség $(29,30)$, sőt mi több állításuk szerint az $\mathrm{I}_{\mathrm{f}}$-áram nem jelentős tényező a spontán automácia létrehozásában, hiszen az $\mathrm{I}_{\mathrm{f}} \mathrm{CsCl}_{2}$-al történő gátlása során kevesebb, mint 20\%-os frekvenciacsökkenést tapasztaltak. Ez utóbbi állítást Dlfrancesco és munkacsoportja hevesen cáfolta (31), egy szerkesztőnek címzett levélben, amellyel egy hosszan tartó vita kezdett kibontakozni. Érveik szerint a korábban alkalmazott $\mathrm{CsCl}_{2}$-koncentráció nem elégséges az $\mathrm{I}_{\mathrm{f}}$ teljes gátlására, valamint $\mathrm{a}$ rianodinnal történő $\mathrm{Ca}^{2+}$-depléció jelentősen befolyásolja azokat a $\mathrm{Ca}^{2+}$-függő mechanizmusokat, amelyek a normál automáciához, és a $\beta$-adrenerg modulációhoz szükségesek (32).

\section{"Membrán óra"” hipotézis versus „"Ca $\mathrm{Ca}^{2+}$-óra” hipotézis: érvek és ellenérvek}

A 2000-es évek elejére nyilvánvalóvá vált, hogy két konkurens mechanizmus áll egymással szemben a spontán automácia magyarázatára: a DIfrancesco és munkacsoportja által képviselt $\mathrm{I}_{\mathrm{f}}$ (pacemaker) áram és a föleg Lakatta és csoportja által kutatott intracelluláris $\mathrm{Ca}^{2+}$-mozgások. A vita nem is elsősorban az egyik vagy másik folyamat meglétéről folyt, hanem sokkal inkább arról, hogy melyik mechanizmus a domináns a másik felett.

2003-ban, a DIfrancesco csoport (33) közölt egy tanulmányt, amelyben eredményeik szerint a rianodin valóban lassítja a frekvenciát, de a bradycardia oka a pozitívabbá váló küszöbpotenciál, és nem a DD-depolarizáció meredekségének csökkenése. Véleményük szerint a spontán $\mathrm{Ca}^{2+}$-felszabadulások (LCR) a T-típusú $\mathrm{Ca}^{2+}$-csatorna működésének eredményeképpen jönnek létre, fokozzák az ingerképzés biztonságát, de nem befolyásolják érdemben a DD-depolarizáció meredekségét. Továbbá a $\beta$-adrenerg moduláció nem függ az SR $\mathrm{Ca}^{2+}$-tartalmától, mert az $\mathrm{I}_{\mathrm{f}}$-áram érzékeny a cAMP-szintre, és rianodin jelenlétében is fokozza a frekvenciát. Véleményük szerint a rianodin tönkreteszi a normál $\mathrm{Ca}^{2+}$ homeosztázist, amely szükséges a $\beta$-adrenerg moduláció kialakulásáért (33).

2004-ben, mintegy erre reflektálva, Lakatta és munkacsoportja további jelentős eredményekkel körvonalazta a $\mathrm{Ca}^{2+}$-ciklus automáciát szabályozó szerepét. A lokális $\mathrm{Ca}^{2+}$-felszabadulások (LCR), ritmikusak nem igényelnek előzetes membránpotenciál-változást, így $\mathrm{Ca}^{2+}$-csatorna nem szükséges kiváltásukhoz. Minden LCR egy befelé irányuló áramimpulzust (NCX) indukál, amely hozzájárulhat a DD-hez, továbbá az LCR-ek periódusideje szoros kapcsolatban áll az AP-k ciklushosszával, így az LCR-ek frekvenciája fontos szabályozó tényező (34). Megállapították, hogy a DD két részre osztható a korai, lineáris rész elsősorban az $\mathrm{I}_{\mathrm{f}}$ és az $\mathrm{I}_{\mathrm{Kr}}$-deaktiváció szabályozása alatt áll, míg a késő nonlineáris rész, amely alatt az LCR-ek történnek, az NCX által szállított befelé irányuló $\mathrm{Na}^{+}$-áram révén jön létre (35). Nyúlsejteken, szimulált iszkémia modellben végzett kísérletek során azt találták (36), hogy az iszkémia-indukált bradycardiában az $\mathrm{I}_{\mathrm{f}}, \mathrm{I}_{\mathrm{Kr}}$ és $\mathrm{I}_{\text {Cal }}$-áramok amplitúdója és kinetikája nem változik, ugyanakkor az $\mathrm{I}_{\mathrm{CaT}}$ és az $\mathrm{I}_{\mathrm{NCX}}$ amplitúdója csökken. Később eredményeiket Maltsev és Lakatta úgy magyarázta, hogy az iszkémia-indukált bradycardia fő előidézője a befelé irányuló NCX-áram csökkenése, ami támogatja a korábbi $\mathrm{Ca}^{2+}$ pacemaker szerepéről alkotott hipotézist (37). Ebben a közleményben került bevezetésre a „Ca $\mathrm{Ca}^{2+}$-óra” hipotézis, amelynek lényege, hogy a SAN-sejtekben, az $\mathrm{I}_{\mathrm{CaL}}$-indukált $\mathrm{Ca}^{2+}$-felszabadulás előtt (a diasztolés fázisban), kis amplitúdójú, szinkronizált, periodikus, előzetes membránpotenciál-változást nem igénylő $\mathrm{Ca}^{2+}$-felszabadulások történnek (LCR). A Ca ${ }^{2+}$-ionok az NCX forward ak- 
tivitása következtében eltávolításra kerülnek, így járulva hozzá a DD-depolarizáció késői, nonlineáris szakaszához. A Ca ${ }^{2+}$-óra frekvenciáját az LCR-periódus hossza határozza meg, amely mindig valamivel rövidebb, mint maga a ciklushossz. A Ca ${ }^{2+}$-óra frekvenciája változó, elsősorban az SR $\mathrm{Ca}^{2+}$ telítettsége szabályozza, amelyet viszont a SERCA és RyR foszforiláltsága határoz meg. $\mathrm{A} \mathrm{Ca}^{2+}$-óra szoros kapcsolatban van mind az NCX-szel, amely befelé irányuló áramot generál, mind az $\mathrm{I}_{\mathrm{CaL}}$-lal, amely a CICR révén kiüríti az SR-t, így az adott ciklusban kialakult LCR-periódus véget ér („reset”), azaz az elmélet szerint a pacemaker-mechanizmusban az NCX alapvető fontosságú, viszont az $I_{\mathrm{K}}$ és $\mathrm{I}_{\mathrm{f}}$ kizárólag a maximális DD-depolarizáció kialakításáért, és a spontán DD-depolarizáció inicializálásáért felelős. Az I $\mathrm{I}_{\mathrm{f}}$ automáciában játszott minimális szerepét áramfeszültség karakterisztikájával (kis áram a SAN DD-depolarizáció tartományában), aktivációs kinetikájával (túl lassú), és a gátlása után $\left(\mathrm{CsCl}_{2}\right.$, ivabradin) mért csekély mértékü bradycardiával magyarázzák $(22,29,37,38)$.

A számos felsorakoztatott kísérleti eredményt követően a DIfrancesco csoport egyre kevésbé vitatta, hogy a $\mathrm{Ca}^{2+}$-ciklus normál körülmények között hozzájárulhat a frekvenciaszabályozáshoz, inkább (39) azt vizsgálta, hogy a két „konkurens” mechanizmus közül melyik lehet alapvetően felelős az "effektor” mechanizmus az autonóm szabályzás frekvenciamodulációjáért. Kísérleteik alapján arra következtetésre jutottak, hogy közepes dózisú $\beta$-adrenerg, illetve muszkarin-receptor-modulátorok alkalmazása esetén a frekvenciaszabályozás elsődleges effektora az $\mathrm{I}_{\mathrm{f}}$-áram. Ugyanakkor nagyobb dózisoknál nem zárható $\mathrm{ki}$ a $\mathrm{Ca}^{2+}$-ciklus szerepe, továbbá megjegyezi, hogy a DD-meredekségének elsődleges szabályzója az $\mathrm{I}_{\mathrm{f}}$, a $\mathrm{Ca}^{2+}$-ciklus változásai leginkább a DD utáni eseményeket befolyásolják.

\section{Közeledő álláspontok: a „kapcsolt-óra hipotézis"}

Az egyre bővülő kísérleti adathalmaz egyaránt támogatta az $\mathrm{l}_{\mathrm{f}}$-hipotézist és a $\mathrm{Ca}^{2+}$-óra hipotézist is, ezáltal egyik fél sem tudta a másik fél által javasolt mechanizmus jelentőségét cáfolni (40). Az ingerképzés komplex voltát mindkét mechanizmus képviselője elismerte, azonban a domináns szerepet illetően továbbra is heves vita folyt. 2010-ben Lakatta és Maltsev (41) egy új, numerikus modellt dolgozott ki, amelynek a „kapcsolt-óra" hipotézist adták. Az új matematikai modell az automáciát már egy komplex mechanizmusként írja le, amelyben a transzszarkolemmális áramok („membrán-óra”) és a $\mathrm{Ca}^{2+}$-óra egymással összhangban, csatoltan müködnek.

A paradigmaváltást az is előmozdította, hogy 2011ben a $\mathrm{Ca}^{2+}$-óra mint önálló pacemaker-mechanizmus hitelessége súlyosan megkérdőjeleződött. Himeno és munkatársai (42) egy rendkívül meggyőző bizonyíték- kal álltak elő az $\mathrm{I}_{\mathrm{f}}$-hipotézis mellett. $\mathrm{Ca}^{2+}$-kelátort tartalmazó patch-clamp elektróddal perforált patch módban regisztráltak AP-t tengerimalac SAN-sejtekböl. Ezt követően a sejtmembránt átszakítva pufferelték az intracelluláris tér $\mathrm{Ca}^{2+}$-terét, amelynek hatására a kontrakció megszűnt, ugyanakkor az AP-aktivitás megmaradt, mindössze az AP időtartama és a frekvencia nőtt kismértékben. Egy másik munkában HCN4-gén kiütött egérmodellt vizsgáltak, ahol a kontrollhoz képest több mint 50\%-os bradycardiát találtak (43). Végül, egy Cav1.3 gén kiütött egérmodellben azt találták, hogy az LCR-frekvencia több mint $70 \%$-kal lecsökkent a vad típushoz viszonyítva. Ez a három eredmény az alábbi következtetésekhez vezetett:

- a $\mathrm{Ca}^{2+}$-óra mechanizmus nem lehet az automácia elsődleges meghatározója,

- a $\mathrm{Ca}^{2+}$-óra mechanizmus nem magyarázza Himeno és munkatársai eredményét, míg a transzmembrán ionáramok $\left(\mathrm{I}_{\mathrm{CaL}}, \mathrm{I}_{\mathrm{CaT}}, \mathrm{I}_{\mathrm{f}}\right.$, háttéráramok) kooperációja lévén létrejövő mechanizmus („membrán-óra hipotézis”) igen,

- az I I-áram speclfikus pacemaker-szabályozó szereppel rendelkezik, valamint

- az LCR nem spontán folyamat, hanem a Cav1.3 csatorna révén kialakuló feszültségfüggő mechanizmus. Lakatta és munkatársai a Himeno és munkatársai által közölt eredményeket elsősorban az alkalmazott metodika során fellépő problémákkal magyarázták (44).

Habár továbbra sem teljes az egyetértés, és vannak kérdéses pontok, úgy tủnik, a Maltsev-Lakatta-féle kapcsolt-óra mechanizmus legújabb verzióját a DIfrancesco csoport is hajlandó elfogadni. A jelenleg regnáló kapcsolt-óra hipotézis, amely mai tudásunk szerint magyarázatot ad az SA-csomó pacemaker-mechanizmusára, az alábbi tulajdonságokkal jellemezhető:

- a membrán ioncsatornái (membrán-óra) és az SR $\mathrm{Ca}^{2+}$-felszabadulás (LCR, $\mathrm{Ca}^{2+}$-óra) rendkívül komplex összhangban müködik: az LCR-eket nemcsak az SR $\mathrm{Ca}^{2+}$-tartalma szabályozza, hanem a membrán ioncsatornáinak foszforiláltsági állapota is. A két óra között reciprok kapcsolat van.

- A két folyamat közül egyik sem domináns, egymást kiegészítve hozzák létre a DD-t. Az If-áram gátlása ivabradinnal csökkenti az SR $\mathrm{Ca}^{2+}$-tartalmát, így következményesen gyengül az NCX-áram is (45).

- Az aktuális ciklushosszt a két óra közötti szinkronizáció mértéke határozza meg: szorosabb csatolás rövidebb ciklushosszt és nagyobb frekvenciát eredményez, és versa vice (46).

- A szinkronizáció mértéke befolyásolja az AP-variabilitást is (47).

- A $\beta$-adrenerg moduláció G-protein-AC-PKA-CamKII kaszkádon keresztül foszforilálja mindkét óra fehérjéit, így fokozza a kapcsolt-óra mechanizmus hatékonyságát (48).

- A két óra csatolásának mértéke ütésről-ütésre változhat, amennyiben az egyik óra mechanizmusában zavar keletkezik $(49,50,46)$. 
- A kapcsolt-óra mechanizmust jelenleg legjobban leíró modell a módositott Maltsev-Lakatta-modell (50), amely kielégítően magyarázza az összes kísérletes eredményt.

Fontos azonban megjegyezni, hogy úgy tünik, hogy az SA-csomó spontán működése nem állítható le még nagy dózisú ivabradinnal, illetve rianodinnal sem (45). Ez az eredmény azt sugallja, hogy habár mind az $\mathrm{I}_{\mathrm{f}}$ mind az NCX fontos szerepet játszik az aktuális frekvencia meghatározásában, a háttér depolarizáló áramok, és a repolarizáló $\mathrm{K}^{+}$-áramok szerepe szintén jelentős a spontán ingerképzés kialakulásában (51).

\section{Következtetések}

Az ingerképzés mechanizmusának problémája közel 20 éves vita után megoldódni látszik, és a szerzők inkább annak kóros müködése felé fordultak. A végső (?) következtetés tehát az lehet, hogy sem a membrán-óra, sem a $\mathrm{Ca}^{2+}$-óra nem domináns a másik felett, hanem egymást kiegészítve, kapcsoltan müködnek. Ezek alapján az ingerképzés egy jelentősen túlbiztosított folyamatnak tủnik, ami nem egyedülálló az élővilágban. A szív repolarizációs folyamata, a stabil nyugalmi membránpotenciál fenntartása, a pozitív inotrópia kialakulása stb., szintén multifaktoriális folyamatok, több mechanizmus összehangolt müködésének eredményei. Ez a „túlbiztosítás” a SA-csomó esetében az élet zálogának tekinthető, hiszen az ingerképzés akár csak néhány másodpercre történő felfüggesztése is nagyon súlyos, akár halálos következményekkel járhat.

A fent vázolt eredmények azonban közel sem jelentik azt, hogy mindent ismerünk a spontán automáciával kapcsolatban. A szelektív gátlószerek hiánya, illetve a folyamat magas fokú komplexitása miatt továbbra sem tekinthetö tisztázottnak a régi kérdés, hogy milyen mértékü az egyes mechanizmusok szerepe a teljes folyamaton belül, és mennyire képesek valamely részfolyamat kiesését kompenzálni. Továbbá válaszra vár az a kérdés is, hogy az egyes SA-funkciót deprimáló folyamatok (pl. szívelégtelenség) hogyan változtatják meg ezt a bonyolult folyamatot. Ezekben a kérdésekben, de talán még a normálfunkciót illetően is, további hosszú és érdekes vitákra számíthatunk.

\section{Köszönetnyilvánítás}

Jelen munkát a Nemzeti Kutatási, Fejlesztési és Innovációs Hivatal (NKFIH K-119992, K-115397, NN109904, ANN-113273, GINOP-2.3.2-15-2016-00006, GINOP-2.3.2-15-2016-00012, and GINOP-2.3.2-152016-040), valamint a LIVE LONGER EFOP-3.6.2-162017-00006 támogatta.

Irodalom

1. Weidmann S. Effect of current flow on the membrane potential of cardiac muscle. J Physiol 1951; 115: 227-36. https://doi.org/10.1113/ jphysiol.1951.sp004667

2. Barbuti A, DIfrancesco D. Control of cardiac rate by "funny" channels in health and disease. Ann N Y Acad Sci 2008; 1123: 213-23. https://doi.org/10.1196/annals.1420.024

3. Carmeliet EE Chloride ions and the membrane potential of Purkinje fibres. J Physiol 1961; 156: 375-88. https://doi.org/10.1113/jphysiol.1961.sp006682

4. Hall AE, Hutter OF, Noble D. Current-voltage relations of Purkinje fibres in sodium-deficient solutions. J Physiol 1963; 166:225-40. https://doi.org/10.1113/jphysiol.1963.sp007102

5. Vassalle M. Analysis of cardiac pacemaker potential using a "voltage clamp" technique. Am J Physiol 1966; 210: 1335-41.

6. Noble D. A modlfication of the Hodgkin--Huxley equations applicable to Purkinje fibre action and pace-maker potentials. J Physiol 1962; 160: 317-52. https://doi.org/10.1113/jphysiol.1962.sp006849

7. Noble D, Tsien RW. The kinetics and rectlfier properties of the slow potassium current in cardiac Purkinje fibres. J Physiol 1968; 195: 185-214. https://doi.org/10.1113/jphysiol.1968.sp008454

8. Hauswirth O, Noble D, Tsien RW. Adrenaline: mechanism of action on the pacemaker potential in cardiac Purkinje fibers. Science 1968; 162: 916-7. https://doi.org/10.1126/science.162.3856.916

9. Brown HF, DIfrancesco D, Noble SJ. How does adrenaline accelerate the heart? Nature 1979; 280: 235-6. https://doi.org/10.1038/280235a0

10. DIfrancesco D, Ferroni A, Mazzanti M, et al. Properties of the hyperpolarizing-activated current (If) in cells isolated from the rabbit sino-atrial node. J Physiol 1986; 377: 61-88. https://doi.org/10.1113/ jphysiol.1986.sp016177

11. Dlfrancesco D. Characterization of single pacemaker channels in cardiac sino-atrial node cells. Nature 1986; 324: 470-3. https:// doi.org/10.1038/324470a0

12. Dlfrancesco D, Ojeda C. Properties of the current If in the sino-atrial node of the rabbit compared with those of the current iK, in Purkinje fibres. J Physiol 1980; 308:353-67. https://doi.org/10.1113/ jphysiol.1980.sp013475

13. Dlfrancesco D A new interpretation of the pace-maker current in calf Purkinje fibres. J Physiol 1981; 314:359-76. https://doi.org/ 10.1113/jphysiol.1981.sp013713

14. Callewaert G, Carmeliet E, Vereecke J Single cardiac Purkinje cells: general electrophysiology and voltage-clamp analysis of the pace-maker current. J Physiol 1984; 349: 643-61. https://doi. org/10.1113/jphysiol.1984.sp015179

15. Dlfrancesco D. Block and activation of the pace-maker channel in calf purkinje fibres: effects of potassium, caesium and rubidium. J Physiol 1982; 329: 485-507. https://doi.org/10.1113/jphysiol.1982. sp014315

16. DIfrancesco D, Tromba C. Inhibition of the hyperpolarization-activated current $\left(\mathrm{I}_{\mathrm{f}}\right)$ induced by acetylcholine in rabbit sino-atrial node myocytes. J Physiol 1988; 405: 477-91. https://doi.org/10.1113/jphysiol.1988.sp017343

17. DIfrancesco D, Tromba C. Muscarinic control of the hyperpolarization-activated current $\left(\mathrm{I}_{\mathrm{f}}\right)$ in rabbit sino-atrial node myocytes. J Physiol 1988; 405: 493-510. https://doi.org/10.1113/jphysiol.1988. sp017344

18. Noma A, Morad M, Irisawa H. Does the "pacemaker current" generate the diastolic depolarization in the rabbit SA node cells? Pflugers Arch 1983; 397: 190-4. https://doi.org/10.1007/BF00584356

19. Sakmann B, Noma A, Trautwein W. Acetylcholine activation of single muscarinic $\mathrm{K}+$ channels in isolated pacemaker cells of the mammalian heart. Nature 1983; 303: 250-3. https://doi.or$\mathrm{g} / 10.1038 / 303250 \mathrm{a} 0$

20. DIfrancesco D, Ducouret $P$, Robinson RB. Muscarinic modulation of cardiac rate at low acetylcholine concentrations. Science 1989; 243: 669-71. https://doi.org/10.1126/science.2916119

21. Zhou Z, Lipsius SL. Properties of the pacemaker current (If) in 
latent pacemaker cells isolated from cat right atrium. J Physiol 1992; 453: 503-23. https://doi.org/ 10.1113/jphysiol.1992.sp019242

22. Hassalle $M$ The pacemaker current (I(f)) does not play an important role in regulating SA node pacemaker activity. Cardiovasc Res 1995; 30: 309-10.

23. Rigg L, Terrar DA. Possible role of calcium release from the sarcoplasmic reticulum in pacemaking in guinea-pig sino-atrial node. Exp Physiol 1996; 81: 877-80. https://doi.org/10.1113/expphysiol.1996.sp003983

24. Hussain M, Orchard $\mathrm{CH}$. Sarcoplasmic reticulum $\mathrm{Ca}^{2+}$ content, L-type $\mathrm{Ca}^{2+}$ current and the $\mathrm{Ca}^{2+}$ transient in rat myocytes during beta-adrenergic stimulation. J Physiol 1997; 505(Pt 2): 385-402. https://doi.org/10.1111/j.1469-7793.1997.385bb.x

25. Ju YK, Allen DG. Intracellular calcium and $\mathrm{Na}^{+}-\mathrm{Ca}^{2+}$ exchange current in isolated toad pacemaker cells. J Physiol 1998; 508 (Pt 1): 153-66. https://doi.org/ 10.1111/j.1469-7793.1998.153br.x

26. Janvier NC, Boyett MR. The role of $\mathrm{Na}-\mathrm{Ca}$ exchange current in the cardiac action potential. Cardiovasc Res 1996; 32: 69-84. https://doi.org/10.1016/S0008-6363(96)00017-X

27. Ju YK, Allen DG. How does beta-adrenergic stimulation increase the heart rate? The role of intracellular $\mathrm{Ca}^{2+}$ release in amphibian pacemaker cells. J Physiol 1999; 516 (Pt 3): 793-804. https://doi. org/10.1111/j.1469-7793.1999.0793u.x

28. Bogdanov KY, Vinogradova TM, Lakatta EG. Sinoatrial nodal cell ryanodine receptor and $\mathrm{Na}(+)-\mathrm{Ca}(2+)$ exchanger: molecular partners in pacemaker regulation. Circ Res 2001; 88: 1254-8. https://doi.org/10.1161/hh1201.092095

29. Vinogradova TM, Bogdanov KY, Lakatta EG. beta-Adrenergic stimulation modulates ryanodine receptor $\mathrm{Ca}(2+)$ release during diastolic depolarization to accelerate pacemaker activity in rabbit sinoatrial nodal cells. Circ Res 2002; 90: 73-9. https://doi.org/10.1161/ hh0102.102271

30. Accili EA, Proenza C, Baruscotti M, et al. From funny current to HCN channels: 20 years of excitation. News Physiol Sci 2002; 17: 32-7.

31. DIfrancesco D, Robinson RB. Beta-modulation of pacemaker rate: novel mechanism or novel mechanics of an old one? Circ Res 2002; 90: E69-9. https://doi.org/10.1161/01.RES.0000014803.05780.E7

32. Vinogradova TM, Bogdanov KY, Lakatta EG. Novel perspectives on the beating rate of the heart. Circ Res 2002; 91: e3. https://doi. org/10.1161/01.RES.0000031164.28289.55

33. Bucchi A, Baruscotti M, Robinson RB, et al. I(f)-dependent modulation of pacemaker rate mediated by CAMP in the presence of ryanodine in rabbit sino-atrial node cells. J Mol Cell Cardiol 2003; 35: 905-13. https://doi.org/10.1016/S0022-2828(03)00150-0

34. Vinogradova TM, Zhou YY, Maltsev V, et al. Rhythmic ryanodine receptor $\mathrm{Ca}^{2+}$ releases during diastolic depolarization of sinoatrial pacemaker cells do not require membrane depolarization. Circ Res 2004; 94: 802-9. https://doi.org/10.1161/01. RES.0000122045.55331.0F

35. Bogdanov KY, Maltsev VA, Vinogradova TM, et al. Membrane potential fluctuations resulting from submembrane $\mathrm{Ca}^{2+}$ releases in rabbit sinoatrial nodal cells impart an exponential phase to the late diastolic depolarization that controls their chronotropic state. Circ Res 2006; 99: 979-87. https://doi.org/10.1161/01. RES.0000247933.66532.0b

36. Du YM, Nathan RD. Ionic basis of ischemia-induced bradycardia in the rabbit sinoatrial node. J Mol Cell Cardiol 2007; 42: 315-25. https://doi.org/10.1016/j.yjmcc.2006.10.004

37. Maltsev VA, Lakatta EG. Cardiac pacemaker cell failure with preserved I(f), I(CaL), and I(Kr): a lesson about pacemaker function learned from ischemia-induced bradycardia. J Mol Cell Cardiol 2007; 42: 289-94. https://doi.org/10.1016/j.yjmcc.2006.11.009
38. Lakatta EG, Maltsev VA, Bogdanov KY, et al. Cyclic variation of intracellular calcium: a critical factor for cardiac pacemaker cell dominance. Circ Res 2003; 92: e45-50. https://doi.org/10.1161/01. RES.0000055920.64384.FB

39. Bucchi A, Baruscotti M, Robinson RB, et al. Modulation of rate by autonomic agonists in SAN cells involves changes in diastolic depolarization and the pacemaker current. J Mol Cell Cardiol 2007; 43: 39-48. https://doi.org/10.1016/j.yjmcc.2007.04.017

40. Lakatta EG, DIfrancesco D. What keeps us ticking: a funny current, a calcium clock, or both? J Mol Cell Cardiol 2009; 47: 157-70. https://doi.org/10.1016/j.yjmcc.2009.03.022

41. Maltsev VA, Lakatta EG. Synergism of coupled subsarcolemmal $\mathrm{Ca}^{2+}$ clocks and sarcolemmal voltage clocks confers robust and flexible pacemaker function in a novel pacemaker cell model. Am J Physiol Heart Circ Physiol 2009; 296: H594-615. https://doi. org/10.1152/ajpheart.01118.2008

42. Himeno Y, Toyoda F, Satoh H, et al. Minor contribution of cytosolic $\mathrm{Ca}^{2+}$ transients to the pacemaker rhythm in guinea pig sinoatrial node cells. Am J Physiol Heart Circ Physiol 2012; 300: H251-61. https://doi.org/10.1152/ajpheart.00764.2010

43. Baruscotti M, Bucchi A, Viscomi C, et al. Deep bradycardia and heart block caused by inducible cardiac-speclfic knockout of the pacemaker channel gene Hcn4. Proc Natl Acad Sci U S A 2011; 108 : 1705-10. https://doi.org/10.1073/pnas.1010122108

44. Maltsev VA, Vinogradova TM, Stern MD, et al. Letter to the editor: "Validating the requirement for beat-to-beat coupling of the $\mathrm{Ca}^{2+}$ clock and M clock in pacemaker cell normal automaticity". Am J Physiol Heart Circ Physiol 2011; 300:H2323-4; author reply H2325-6. https://doi.org/10.1152/ajpheart.00110.2011

45. Yaniv Y, Sirenko S, Ziman BD, et al. New evidence for coupled clock regulation of the normal automaticity of sinoatrial nodal pacemaker cells: bradycardic effects of ivabradine are linked to suppression of intracellular $\mathrm{Ca}(2)(+)$ cycling. J Mol Cell Cardiol 2013; 62: 80-9. https://doi.org/10.1016/j.yjmcc.2013.04.026

46. Monfredi O, Maltseva LA, Spurgeon HA, et al. Beat-to-Beat Variation in Periodicity of Local Calcium Releases Contributes to Intrinsic Variations of Spontaneous Cycle Length in Isolated Single Sinoatrial Node Cells. PLoS One 2013; 8: e67247. https://doi. org/10.1371/journal.pone.0067247

47. Yaniv $Y$, Lyashkov AE, Sirenko S, et al. Stochasticity intrinsic to coupled-clock mechanisms underlies beat-to-beat variability of spontaneous action potential firing in sinoatrial node pacemaker cells. J Mol Cell Cardiol 2014; 77: 1-10. https://doi.org/10.1016/j.yjmcc.2014.09.008

48. Yaniv Y, Ahmet I, Liu J, et al. Synchronization of sinoatrial node pacemaker cell clocks and its autonomic modulation impart complexity to heart beating intervals. Heart Rhythm 2014; 11: 1210-9. https://doi.org/10.1016/j.hrthm.2014.03.049

49. Yaniv Y, Maltsev VA, Escobar AL, et al. Beat-to-beat $\mathrm{Ca}(2+)$-dependent regulation of sinoatrial nodal pacemaker cell rate and rhythm. J Mol Cell Cardiol 2011; 51: 902-5. https://doi.org/10.1016/j.yjmcc.2011.08.029

50. Yaniv $Y$, Stern MD, Lakatta EG, et al. Mechanisms of beat-tobeat regulation of cardiac pacemaker cell function by $\mathrm{Ca}(2)(+)$ cycling dynamics. Biophys J 2013; 105: 1551-61. https://doi.org/ 10.1016/j.bpj.2013.08.024

51. Lengyel C, Varró A, Tábori K, et al. Combined pharmacological block of $\mathrm{I}(\mathrm{Kr})$ and $\mathrm{I}(\mathrm{Ks})$ increases short-term QT interval variability and provokes torsades de pointes. $\mathrm{Br} \mathrm{J}$ Pharmacol 2007; 151: 941-51. 